ЕНЕРГЕТИКА. ТЕПЛОТЕХНІКА.

UDC 628.165.048+621.577.4

V.P. Kravchenko, DSc, Prof.,

S.V. Surkov, PhD, Assoc.Prof.,

Hussam Ghanem

Odessa National Polytechnic University, 1 Shevchenko Ave., 65044 Odessa, Ukraine; e-mail: surkov101@mail.ru

\title{
MODELLING AND OPTIMIZATION OF SEAWATER DESALINATION PROCESS USING MECHANICAL VAPOUR COMPRESSION
}

В.П. Кравченко, С.В. Сурков, Хуссам Ганем. Моделювання й оптимізація процесу опріснення морської води в установках $з$ механічним стисненням пари. В умовах глобальних змін клімату нестача прісної води стає актуальною проблемою для все більшої кількості країн. Однією з найбільш перспективних технологій опріснення морської води є механічне стиснення пари (МСП), що забезпечує низьке енергоспоживання завдяки використанню принципу теплового насоса. Мета: Метою роботи $\epsilon$ виявлення резервів підвищення ефективності опріснювальних систем, заснованих на механічному стисненні пари, шляхом оптимізації схеми і параметрів установок з МСП. Матеріали $\boldsymbol{i}$ методи: Запропоновано новий тип опріснювальної установки, головним елементом якої є теплообмінник прихованої теплоти. Морська вода після попереднього нагрівання в теплообмінниках надходить у випарник-конденсатор, де отримує основну кількість теплоти від пари, що конденсується. Частина морської води випаровується, а концентрований розчин солі (розсіл) виходить 3 випарника і після охолодження скидається назад в море. Пара, що утворюється, стискається за допомогою компресора і надходить у конденсатор. Суттєвою особливістю даної схеми $є$ те, шо конденсація відбувається при вищих температурах, ніж випаровування. Завдяки цьому теплота, що виділяється при конденсації пари, використовується для випаровування морської води. Результати: Було вирішено наступні питання: модифікована і доповнена математична модель установок з МСП, модифіковано схему включення теплообмінників, досліджено вплив конструктивних параметрів установки на вартість обладнання і електроенергії. Аналіз схем установки і математичної моделі дозволив визначити шляхи зниження енерговитрат. Проаналізовано вплив двох основних параметрів - питомої потужності компресора й питомої площі поверхні випарникаконденсатора - на величину приведених витрат опріснювальної установки. Визначено оптимальне співвідношення цих параметрів.

Ключові слова: опріснення морської води, механічне стиснення пари, чисельне моделювання.

V.P. Kravchenko, S.V. Surkov, Hussam Ghanem. Modelling and optimization of seawater desalination process using mechanical vapour compression. In the conditions of global climate changes shortage of fresh water becomes an urgent problem for an increasing number of the countries. One of the most perspective technologies of a desalting of sea water is the mechanical vapour compression (MVC) providing low energy consumption due to the principle of a heat pump. Aim: The aim of this research is to identify the reserves of efficiency increasing of the desalination systems based on mechanical vapour compression by optimization of the scheme and parameters of installations with MVC. Materials and Methods: The new type of desalination installation is offered which main element is the heat exchanger of the latent heat. Sea water after preliminary heating in heat exchangers comes to the evaporator-condenser where receives the main amount of heat from the condensed steam. A part of sea water evaporates, and the strong solution of salt (brine) goes out of the evaporator, and after cooling is dumped back in the sea. The formed steam is compressed by the compressor and comes to the condenser. An essential singularity of this scheme is that condensation happens at higher temperature, than evaporation. Thanks to this the heat, which is comes out at devaporation, is used for evaporation of sea water. Thereby, in this class of desalination installations the principle of a heat pump is implemented. Results: For achievement of a goal the following tasks were solved: the mathematical model of installations with MVC is modified and supplemented; the scheme of heat exchangers switching is modified; influence of design data of desalination installation on the cost of an inventory and the electric power is investigated. The detailed analysis of the main schemes of installation and mathematical model allowed defining ways of decrease in energy consumption and the possible merit value. Influence of two key parameters - a specific power of the compressor and a specific surface area of the evaporator-condenser - on a value of given expenses of desalination installation is analyzed. The optimum ratio of these parameters is defined.

Keywords: desalting of sea water, mechanical vapour compression, numerical modeling.

Introduction. Now the need for fresh water, both for domestic needs and for the production enterprises, grows in many countries of the world. Especially this problem is particularly acute in the 
countries of the Arabian Peninsula and the Persian Gulf. As of 2008 the Persian Gulf countries were producing $58 \%$ of the bulk world volume of desalinated water. Global climate changes and population growth do a problem of fresh water more and more urgent for the majority of regions of the Globe [1].

Especially high requirements for the consumed water are placed by heat power production. On nuclear power plants water is used as a working medium and as the coolant. Effectiveness of thermal energy transfer and the its subsequent transformation into a mechanical energy is defined by purity of surfaces of metal contacting with water and steam. According to technical requirements, the quantity of permeates in working water must be no more than $10 \mu \mathrm{g} / 1$ [2].

The required quality of water can be reached only by means of technologies of a thermal desal ting (distillation) which have several modifications. Multistage installations of instantaneous flashing (MSF) are mainly used in large stationary installations. In the presence of the industrial vapor sources the installations with thermal vapour compression (TVC) are optimum. Far from the industrial vapour sources and in mobile installations the technology of a desalting with mechanical vapour compression (MVC) has the greatest advantages. In this research this technology is chosen for the detailed analysis.

In the works of El-Dessouky [3] and Al-Juwayhel et al. [4] the mathematical models of systems with MVC are developed. Further researches were devoted to decrease in prime cost of the water freshened with MVC use. In particular, Lara [5,6] investigated the prospects of use of high performance gerotor compressors and hydrophobic evaporators-condensers, and Cherkasskiy [7] investigated high-temperature working modes.

The aim of this research is to identify the reserves of efficiency increasing of the desalination systems based on mechanical vapour compression by optimization of the scheme and parameters of installations with MVC.

To achieve the goal, it is necessary to solve the following problems:

- to modify and complete the mathematical model of installations with MVC;

- increase the convergence of iterative methods and the reliability the obtained results;

— to modify the scheme of heat exchangers plug-in;

- to research the influence of design parameters of desalination installation on the cost of an inventory and the electric power.

Materials and Methods. The scheme of the offered desalination installation is submitted in Fig. 1.

The main element of this installation is a uniform block of the evaporator-condenser, or the latent heat exchanger.

Seawater after preliminary heating in heat exchangers comes to the evaporator-condenser where receives the main heat amount from the condensed vapour. A part of seawater evaporates, and the strong solution of salt (brine) goes out of the evaporator, and after cooling is dumped back in the sea. The formed vapour is compressed by the compressor and comes to the condenser.

The $T(s)$ - chart of process is schematically shown in Fig. 2. Here, the piece 1-2 shows the process of evaporation of seawater; $2-3-$ compression of vapour in the compressor which can be considered as adiabatic; 3-4 isobaric cooling, 4-5 - devaporation.

Essential singularity of this scheme is that condensation takes place at higher temperature, than evaporation. Due to this the heat evolved at devaporation is used for evaporation of seawater. Thereby in this class of desalination installations the principle of a heat pump is implemented.

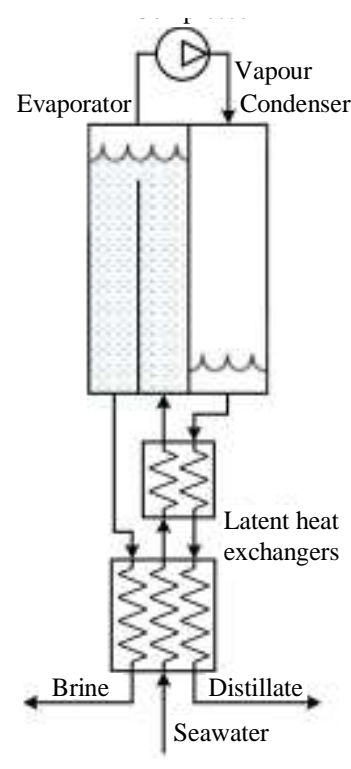

Fig. 1. The scheme of desalination installation with mechanical vapour compression 


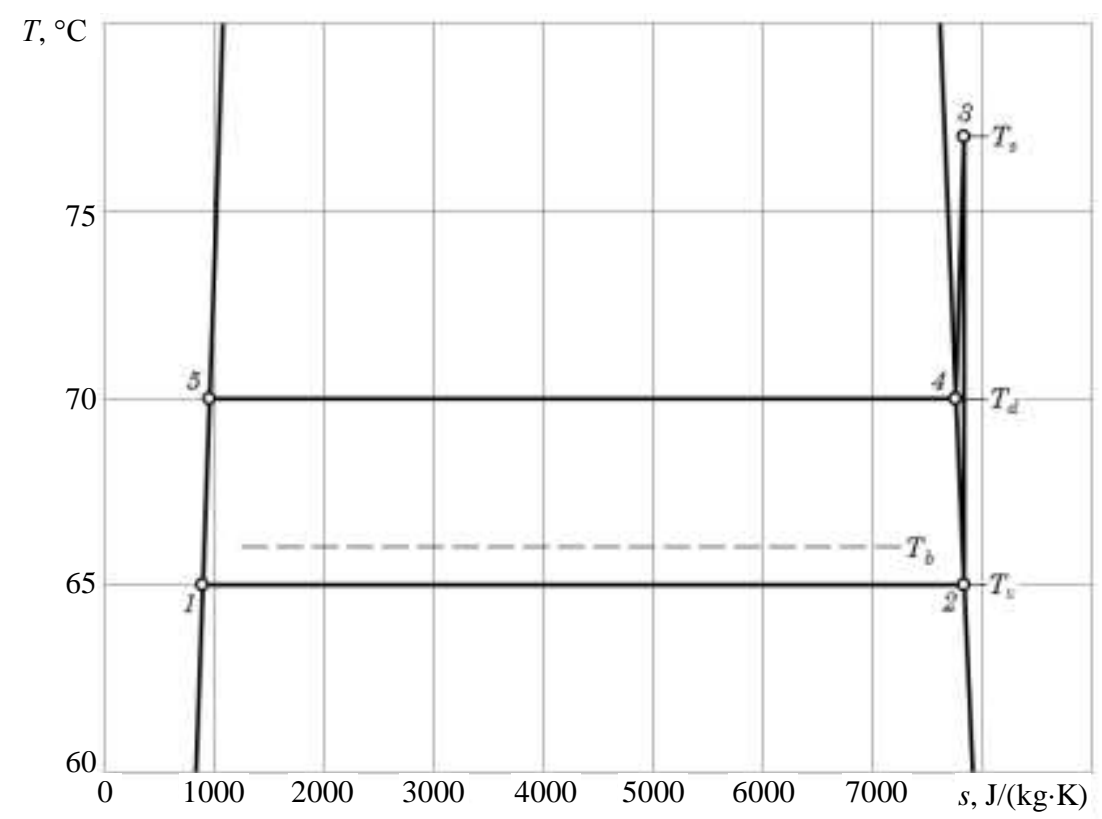

Fig. 2. The $T(s)$ —chart of desalting process with mechanical vapour compression

Now let's write down a weight conservation law for water and for salt respectively:

$$
\begin{gathered}
G_{f}=G_{d}+G_{b}, \\
G_{f} X_{f}=G_{b} X_{b},
\end{gathered}
$$

where $G$ - mass flow of substance (water, salt);

$X$ - salt concentration.

Here indexes $f, d$ and $b$ belong to the feeding ocean water, the distillate and a brine dumped in the sea respectively.

The energy balance for the device in general is calculated according to the equation

$$
h_{c w} G_{f}+W G_{d}=h_{d} G_{d}+h_{b} G_{b},
$$

where $h$-enthalpy,

$W$ - specific energy, transferred to the steam flow from the compressor.

Using mean specific heat $c_{p}$, the equation (3) can be rewritten as

$$
W G_{d}=\left(G_{b}+G_{d}\right) c_{p}\left(T_{o u t}-T_{c w}\right),
$$

where $T_{\text {out }}$ - temperature of the output streams of a brine and distillate,

$T_{c w}$ - temperature of the input seawater.

From here it is possible to obtain

$$
T_{\text {out }}=T_{c w}+\frac{W G_{d}}{c_{p}\left(G_{b}+G_{d}\right)} .
$$

For a numerical example is set that a mass output of distillate is $1 \mathrm{~kg} / \mathrm{s}$.

The amount of heat needed to evaporate the second mass of vapour is calculated using the formula

$$
Q_{2}=G_{d} r_{b},
$$

where $r_{b}$ - latent heat of vaporization at boiling point of a brine. 
The quantity of heat $Q_{2}$ has to be transmitted to the boiling brine through evaporator-condenser walls.

The temperature of vapour which is formed during salty water boiling can be calculated as

$$
T_{v}=T_{b}-B P E,
$$

where $B P E$ - boiling point elevation, which can be calculated according to [3, 4].

The saturation pressure in an evaporator corresponding to temperature $T_{v}$ is calculated by the formula

$$
p_{v}=p_{s}\left(T_{v}\right) .
$$

For further calculations it is necessary to set first approximation for temperature $T_{d}$ at which the vapour in the condenser is condensed. Further value of $T_{d}$ is defined by method of simple iterations

The compressor has to create pressure in the condenser that would be equal to saturated vapor pressure at temperature $T_{d}$, i.e.

$$
p_{d}=p_{s}\left(T_{d}\right) \text {. }
$$

Vapor pressures on the saturation line $p_{s}\left(T_{d}\right)$ and $p_{s}\left(T_{b}\right)$ are also calculated according to the ratios given in [4].

Estimation of minimum necessary intensity of vapour compression in the compressor is made according to the equation

$$
C r=p_{s}\left(T_{d}\right) / p_{s}\left(T_{b}\right) \text {. }
$$

The specific power consumed by the compressor electric motor according to [7] is calculated using formula

$$
W_{c}=\frac{\gamma}{\gamma-1} \frac{p_{v} v_{v}}{\eta}\left[\left(\frac{p_{d}}{p_{v}}\right)^{\frac{\gamma-1}{\gamma}}-1\right],
$$

where $v_{v}$ - specific volume of a saturated vapour at a temperature $T_{v}$;

$\gamma$ - heat capacity ratio;

$\eta$ - compressor efficiency.

Apparently, the following ratio is fair in adiabatic process:

$$
\frac{T_{s}}{T_{v}}=\left(\frac{p_{d}}{p_{v}}\right)^{\frac{\gamma-1}{\gamma}} .
$$

From here it is possible to evaluate the temperature of compressed vapor

$$
T_{s}=T_{v}\left(\frac{p_{d}}{p_{v}}\right)^{\frac{\gamma-1}{\gamma}} .
$$

The heat amount allocated during devaporation process is calculated according to the ratio

$$
Q_{1}=G_{d}\left[r_{d}+c_{p}^{\prime \prime}\left(T_{s}-T_{d}\right)\right],
$$

where $r_{d}$ - latent heat of vaporization at condensation temperature.

As calculations show, this power, as a rule, is more, than $Q_{2}$ because of the "excess" values of $T_{s}$ arising at adiabatic vapour compression in the compressor. Excess of power $\left(Q_{1}-Q_{2}\right)$ in practice leads to boiling temperature $T_{b}$ rise, and together with it — the rise of all other specific temperatures. 
However, in this work authors assume that excess of power is compensated by a thermolysis to ambient medium, and process can be considered as conservative one.

The heat transfer equation can be written as

$$
Q_{2}=U_{e} A_{e}\left(T_{d}-T_{b}\right),
$$

where $U_{e}$ - total heat transfer coefficient of the evaporator-condenser;

$A_{e}$ - area of surface-heat transfer of evaporator-condenser.

At predefined values of $A_{e}$ and $U_{e}$ the condensation temperature id determined uniquely

$$
T_{d}=T_{b}+\frac{Q_{1}}{U_{e} A_{e}},
$$

but, because $U_{e}$ depends on temperature [3], it is necessary the iterative refinement of $T_{d}$.

The loop body containing the equations $(6 \ldots 11)$ repeats until change of $T_{d}$ value becomes less than the preset small value. Calculations show that the iterative cycle converges quickly.

Results and Discussion. All calculations were performed for a hypothetical machine which mass yield of distillate is $1 \mathrm{~kg} / \mathrm{s}$. Thus, all values of power and areas can be considered as appanage. The heat transfer coefficient was calculated by the integral relations given in $[3,4]$, and average value of it is $2.45 \mathrm{~kW} /\left(\mathrm{m}^{2} \cdot \mathrm{K}\right)$.

In fig. 3 the dependence of power and excess of power of the compressor on a heat exchange surface area is shown.

From Fig. 3 it is evident that the necessary compressor power significantly decreases at increase of a heat exchange surface area of evaporator-condenser. The optimum ratio between these parameters can be found based on the economic calculation.

Specific energy consumption on production of one cubic meter of desalinated water is bound to a specific power with the ratio

$$
W=3.6 \cdot N,
$$

where $W$ - specific consumption of the electric power, $(\mathrm{kW} \cdot \mathrm{h}) / \mathrm{m}^{3}$;

$N$ - specific power, $\mathrm{kW} / \mathrm{kg}$.

In Fig. 4 the dependence of specific power consumption of $W$ on temperature of seawater boiling at two various values of heat-transfer coefficient in evaporator-condenser is shown.

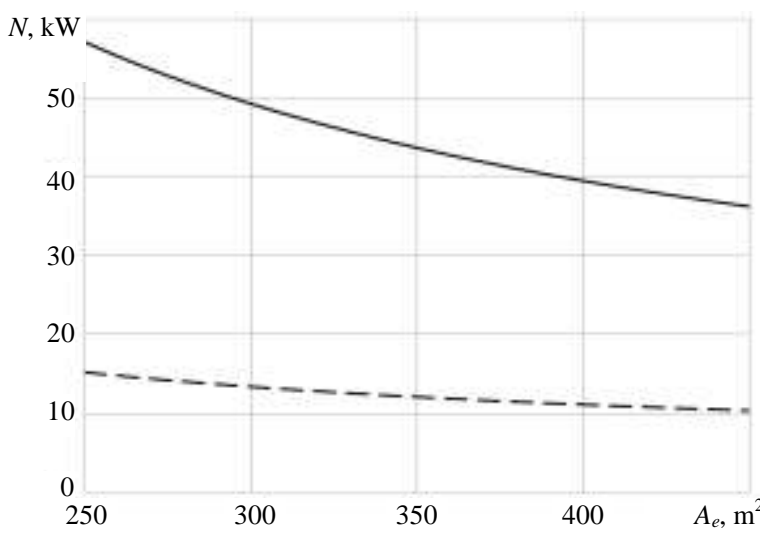

Fig. 3. Dependences of necessary power of the compressor («-》) and excess of a thermal power (《---») on a surface area

of heat exchange of evaporator-condenser

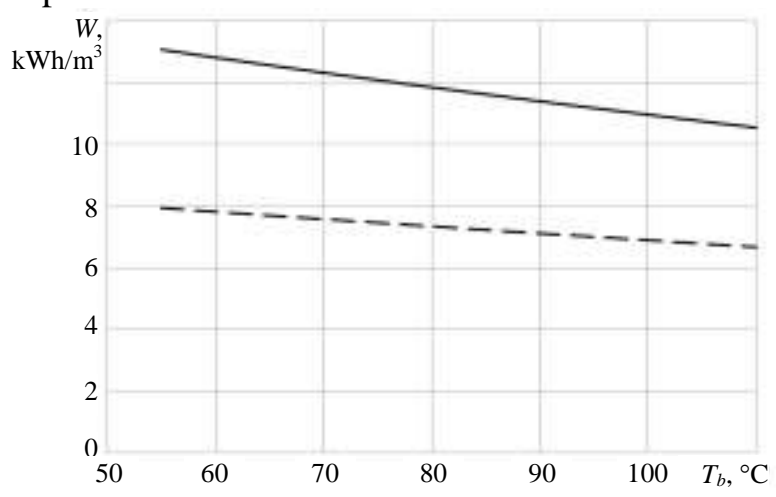

Fig. 4. Dependence of specific power consumption on temperature of seawater boiling at two various values of heat-transfer coefficient in evaporator-condenser:

$$
\begin{aligned}
& \text { «-»- } U_{e}=2,5 \mathrm{~kW} /\left(\mathrm{m}^{2} \cdot \mathrm{K}\right) ; \\
& \text { «--» - } U_{e}=5,0 \mathrm{~kW} /\left(\mathrm{m}^{2} \cdot \mathrm{K}\right)
\end{aligned}
$$


From Fig. 4 it is evident that at increasing of boiling temperature the specific energy consumption and the surplus of power lost are simultaneously decrease. However, at increasing of boiling temperature above $70{ }^{\circ} \mathrm{C}$ the speed of adjournment of a scum on device walls sharply increases that leads to growth of operational expenses.

The system of preliminary water heating consisting of two heat exchangers is offered.

The energy balance for the smaller heat exchanger utilizing heat of distillate can be calculated from the equation

$$
Q_{d}=G_{d} c_{p 1}\left(T_{d}-T_{b}\right)=G_{f} c_{p 2}\left(T_{b}-T_{x}\right)
$$

in turn, for the second heat exchanger utilizing heat of a brine and distillate can be calculated from the equation

$$
Q_{b}=G_{b} c_{p 3}\left(T_{b}-T_{o u t}\right)+G_{d} c_{p 4}\left(T_{b}-T_{o u t}\right)=G_{c w} c_{p 5}\left(T_{x}-T_{c w}\right) .
$$

The $T_{x}$ we evaluate of (12)

and substitute in (13).

$$
T_{x}=T_{b}-\left(T_{d}-T_{b}\right) \frac{G_{d} c_{p 1}}{G_{f} c_{p 2}}
$$

When all temperatures at input and output for each heat exchanger are determined, it is possible to calculate the necessary areas of surfaces of heat exchange. We will calculate log mean temperature pressures according to the following ratios:

$$
\Delta T_{d}^{l m}=\frac{\left(T_{d}-T_{b}\right)-\left(T_{b}-T_{x}\right)}{\ln \frac{T_{d}-T_{b}}{T_{b}-T_{x}}}, \Delta T_{b}^{l m}=\frac{\left(T_{b}-T_{x}\right)-\left(T_{\text {out }}-T_{c w}\right)}{\ln \frac{T_{b}-T_{x}}{T_{\text {out }}-T_{c w}}} .
$$

The necessary surfaces areas of heat exchange are calculated by the formulas:

$$
\begin{aligned}
& A_{d}=\frac{Q_{d}}{U_{d} \Delta T_{d}^{l m}}, \\
& A_{b}=\frac{Q_{b}}{U_{b} \Delta T_{b}^{l m}} .
\end{aligned}
$$

The equations (12..16) give the only solution in whole studied range of temperatures and provide heating of seawater to temperature $T_{b}$.

In Fig. 6 the dependence of the necessary surfaces areas of heat exchange on boiling temperature is $\operatorname{shown} T_{b}$.

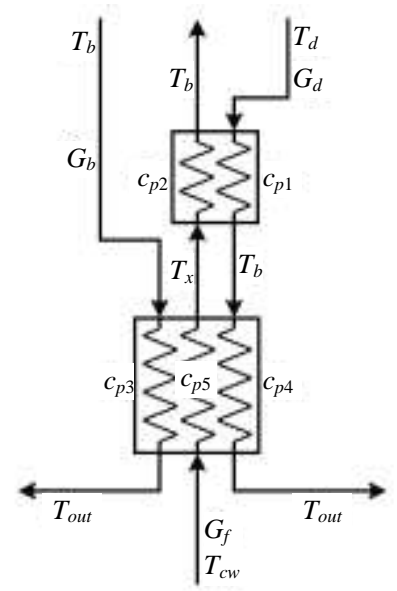

Fig. 5. The scheme of plug-in of heat exchangers of seawater preliminary heating with the indication of temperatures and mass expenses of water

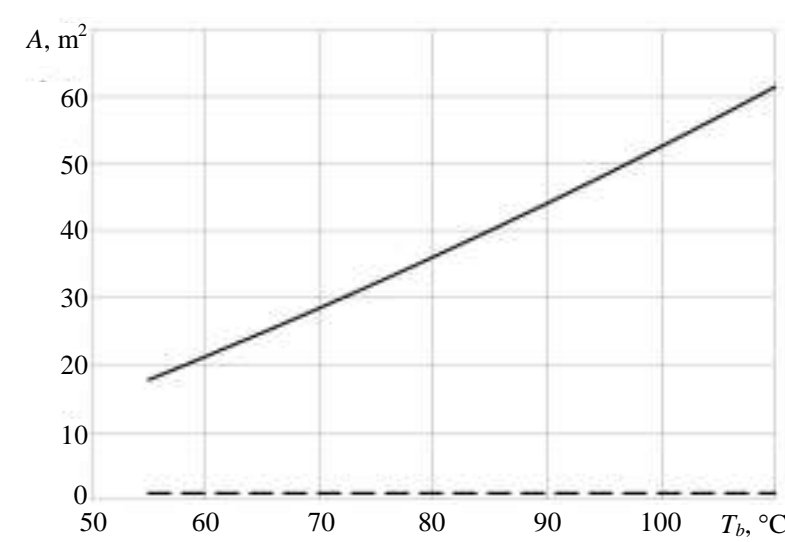

Fig. 6. The necessary surfaces areas of heat exchange for preliminary heaters of seawater:

$$
\text { «-»- } A_{b} ; \ll---»-A_{d}
$$


From the plot it is visible that the areas of surfaces $A_{d}$ for preliminary heat exchangers are 10 times less than the areas of surfaces of evaporator-condenser $A_{b}$. The area $A_{b}$ is greatly rises at rise of boiling temperature $T_{b}$. Therefore, in economic calculation the main attention needs to be paid to the cost of evaporator-condenser.

Criterion of technical and economic optimization. As criterion of comparison the annual given costs are accepted $[8,9]$ :

$$
C=e_{n} C_{c}+C_{o p}
$$

where $e_{n}$ - normative rate of return (assumed equal to 0.12 );

$C_{c}$ - capitalized expenses;

$C_{o p}$ - annual expenditure.

Annual expenditure $C_{o p}$ may be calculated by the formula

$$
C_{o p}=C_{e l .}+C_{\text {clean. }}+C_{a m .}+C_{\text {expl. }},
$$

where $C_{e l .}$ - annual power expenses;

$C_{\text {clean. }}$ - costs of water purification and transfer of salts to a soluble state for prevention of salts loss on the heating surfaces (we accept equal $0.3 \mathrm{USD} / \mathrm{m}^{3}$ of initial water);

$C_{a m .}$ - annual costs for depreciation of capital investments and maintenance estimated at $10 . . .20 \%$ of depreciation expense;

$C_{\text {expl. }}$ - operating expenses.

Annual energy costs are calculated by the formula:

$$
C_{\text {el. }}=A_{\text {el.en. }} P_{e l} \text {, }
$$

where $P_{e l}$ - national electricity cost (for UAE $P_{e l}=0.04 \mathrm{USD} /(\mathrm{kW} \cdot \mathrm{h})$ );

$A_{\text {el.en. }}$ - annual energy consumption, $\mathrm{kWh}$.

Annual costs on depreciation of capital investment and maintenance calculated by the formula

$$
C_{a m .}=p_{a} C_{c}+C_{m}=p_{a} C_{c}+0.1 p_{a} C_{c}=1.1 p_{a} C_{c},
$$

where $p_{a}$-depreciation rate (assumed equal to 0.06 ).

$C_{m}$ - maintenance costs.

Maintenance costs are determined according to the ratio

$$
C_{\text {expl. }}=C_{\text {lab. }}+C_{\text {oth. }},
$$

where $C_{l a b .}$ - annual salary of the staff;

$C_{\text {oth. }}$ - other manufacturing expenses.

The value of manufacturing expenses $C_{\text {oth. }}$ is $20 \ldots 30 \%$ total costs for depreciation, maintenance works and wages, i.e. operating costs are in accordance with the ratio:

$$
C_{\text {expl. }}=C_{\text {lab. }}+0.2\left(p_{a} C_{c}+0.1 p_{a} C_{c}+C_{\text {lab. }}\right)=1.2 C_{\text {lab. }}+0.22 p_{a} C_{c} .
$$

Substituting the values of all components in the expression (18), we obtain the formula for annual operating costs:

$$
C_{o p}=C_{e l .}+C_{\text {clean. }}+1.1 p_{a} C_{c}+1.2 C_{\text {lab. }}+0.22 p_{a} C_{c}=C_{e l .}+1.32 p_{a} C_{c}+1.2 C_{\text {lab. }} .
$$

The expression for the given expenses can be written as

$$
\begin{aligned}
C=e_{n} C_{c}+C_{\text {el. }}+C_{\text {clean. }}+ & 1.32 p_{a} C_{c}+1.2 C_{\text {lab. }}=C_{c}\left(e_{n}+1.32 p_{a}\right)+C_{\text {el. }}+C_{\text {clean. }}+1.2 C_{\text {lab. }}= \\
= & 0.1992 C_{c}+C_{\text {el. }}+C_{\text {clean. }}+1.2 C_{\text {lab. }} .
\end{aligned}
$$


Then, the final expression for the variable part of given expenses takes the form:

$$
C=0.1992 C_{c}+C_{e l .} \text {. }
$$

The needs for the electric power are determined under condition of installation operating within 22 hours a day and 360 days within a year. During the choice of the equipment was accepted that productivity of installation makes $25 \mathrm{~m}^{3}$ per day.

Capital expenditure consists, mainly, of the cost of evaporator-condenser, preliminary heat exchangers and the compressor.

As evaporator-condenser and preliminary heaters of seawater it is expedient to use the lamellar heat exchangers differing in high coefficient of a heat transfer. The analysis of cost of heat exchangers shows that in approximate calculation it is possible to accept their cost of directly proportional to surface area of heat exchange.

For typical in the studied range heat exchanger Ridan NN 41 the surface area of heat exchange is $217.35 \mathrm{~m}^{2}$ at the price of 4806 USD [10]. Then the total cost of heat exchangers can be estimated using the formula

$$
C_{\text {h.e. }}=22.11\left(A_{e}+A_{b}+A_{d}\right) .
$$

Compressor cost $C_{\text {compr. }}$ can be averagely set to proportional power of electric engine. According to [11], $C_{\text {compr. }}=645 \cdot N_{c}$.

Total capital expenditure will be

$$
C_{c}=C_{\text {h.e. }}+C_{\text {compr. }} \text {. }
$$

The given annual costs (17) have been calculated taking into account the power of the compressor and the areas of heat exchange surfaces obtained higher. Results of calculation of the specified cost for installation with a productivity of $1 \mathrm{~kg} / \mathrm{s}$ of desalinated water are presented in Fig. 7.

The analysis of the plots shows that the minimum of the given capital expenditure is reached at the specific area of evaporatorcondenser of $570 \mathrm{~m}^{2}$. The electricity cost continuously drops at increase of surface of heat exchange of evaporator-condenser $A_{e}$. Total annual costs decrease up to value $A_{e}=1000 \mathrm{~m}^{2}$. But at such great areas the heat exchangers have the large weight and dimensions and therefore $A_{e}$ needs to be limited accordingly to transportation cost.

Conclusions. Numerical modeling has

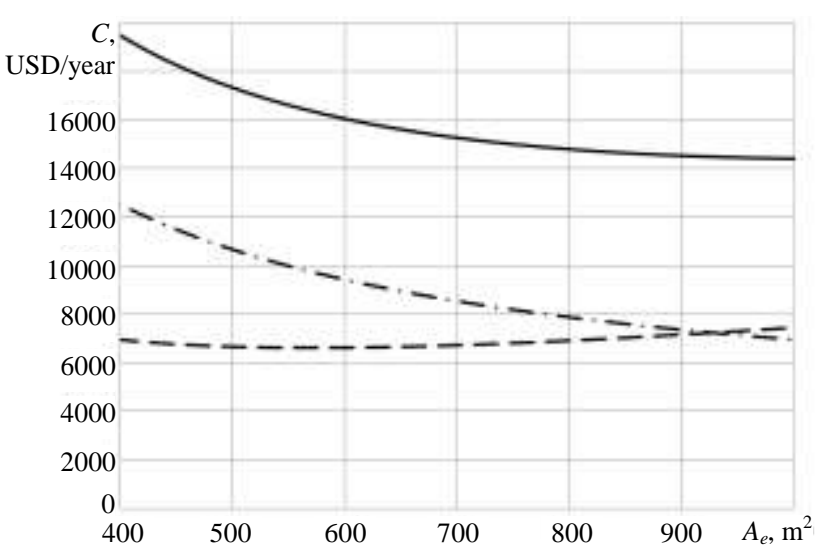

Fig. 7. The given annual costs as function of the surface area of heat exchange of evaporator-condenser: «-»-total annual costs; «---» - reduced capital costs; «- -$\rangle$ - the annual cost of electricity shown that in systems with adiabatic compression of steam there are losses of power which are $26 \ldots 29 \%$ of the general expenses of energy. These losses can be reduced when using advanced processes of compression of vapour along the line of saturation, for example - at injection of water in the compressor.

Decrease in prime cost of desalinated water can be reached mainly due to increase of efficiency of the compressor and increase of a heat transfer coefficient of evaporator-condenser.

With the given productivity of desalination installation, the optimum parameters of the compressor (from the economic point of view) and evaporator-condenser can be found. 


\section{Лiтература}

1. Escobar, I.C. Sustainable water for the future: Water recycling versus desalination / I.C. Escobar, A.I. Schäfer. - Amsterdam; Boston: Elsevier Science, 2010. — 416 p.

2. Копылов, А.С. Водоподготовка в энергетике / А.С. Копылов, В.М. Лавыгин, В.Ф. Очков. - 2-е изд., стер. - М.: Издат. дом МЭИ, 2006. - 309 с.

3. El-Dessouky, H.T. Fundamentals of salt water desalination / H.T. El-Dessouky, H.M. Ettouney. - Amsterdam: Elsevier Science, 2002. - 670 p.

4. Al-Juwayhel, F. Analysis of single-effect evaporator desalination systems combined with vapor compression heat pumps / F. Al-Juwayhel, H. El-Dessouky, H. Ettouney // Desalination. — 1997. — Vol. 114, Issue 3. - PP. 253-275.

5. Lara, J.R. Advanced mechanical vapor-compression desalination system / J.R. Lara, Omorinsola Osunsan, M.T. Holtzapple // Desalination, Trends and Technologies / ed. by M. Schorr. - Rijeka: InTech, 2011. - PP. 129-148.

6. Lara, J.R. An investigation of high operating temperatures in mechanical vapor-compression desalination / J.R. Lara, G. Noyes, M.T. Holtzapple // Desalination. - 2008. — Vol. 227, Issues 1-3. PP. 217-232.

7. Черкасский, В.М. Насосы, вентиляторы, компрессоры / В.М. Черкасский. - М.: Энергоатомиздат, 1984. - $416 \mathrm{c}$.

8. Беренс, В. Руководство по подготовке промышленных технико-экономических исследований: монография / В.Беренс, П.М. Хавранек; пер. с англ. А.О. Гридин и др.; науч.ред. Р.П. Вчерашний и др. - новое перераб. и доп. изд. - М.: Интерэксперт, 1995. — 343 с.

9. Preparation of a Feasibility Study for New Nuclear Power Projects / International Atomic Energy Agency. - Vienna: IAEA, 2014. - 125 p.

10. Типовые цены на Теплообменники пластинчатые [Електронний ресурс] / ТеплоПрофи: Комплексные поставки инженерного оборудования по России и СНГ. - Режим доступу: http://www.teploprofi.com/ceni/ (Дата звернення: 25.05.2016).

11. Оборудование [Електронний ресурс] / ERSTEVAK Ltd. - Режим доступу: http://www.erstvak.com/equipment/ (Дата звернення: 24.05.2016).

\section{References}

1. Escobar, I.C., \& Schäfer, A.I. (2010). Sustainable Water for the Future: Water Recycling Versus Desalination. Amsterdam; Boston: Elsevier Science.

2. Kopylov, A.S., Lavygin, V.M., \& Ochkov, V.F. (2006). Water Treatment in Power Engineering ( $2^{\text {nd }}$ Ed.). Moscow: MEI.

3. El-Dessouky, H.T., \& Ettouney, H.M. (2002). Fundamentals of Salt Water Desalination. Amsterdam: Elsevier Science.

4. Al-Juwayhel, F., El-Dessouky, H., \& Ettouney, H. (1997). Analysis of single-effect evaporator desalination systems combined with vapor compression heat pumps. Desalination, 114(3), 253-275. DOI:10.1016/S0011-9164(98)00017-4

5. Lara, J.R., Omorinsola Osunsan, Holtzapple, M.T. (2011). Advanced mechanical vapor-compression desalination system. In M. Schorr (Ed.), Desalination, Trends and Technologies (pp. 129-148). Rijeka: InTech. DOI: $10.5772 / 14711$

6. Lara, J.R., Noyes, G., \& Holtzapple, M.T. (2008). An investigation of high operating temperatures in mechanical vapor-compression desalination. Desalination, 227(1-3), 217-232. DOI:10.1016/j.desal.2007.06.027

7. Cherkassky, V.M. (1985). Pumps, Fans, Compressors. Moscow: Mir.

8. Behrens, W., \& Hawranek, P.M. (1991). Manual for the Preparation of Industrial Feasibility Studies. Vienna: UNIDO.

9. International Atomic Energy Agency. (2014). Preparation of a Feasibility Study for New Nuclear Power Projects. Vienna: IAEA.

10. TeploProfi. (n.d.). Prices for Lamella Heat-Exchangers. Retrieved from http://www.teploprofi.com/ceni/

11. ERSTEVAK Ltd. (n.d.). Equipment. Retrieved from http://www.erstvak.com/equipment/ 